\title{
Grasshoppers Sphenarium Purpurascens Ch Source of Proteins and Essential Amino Acids
}

\author{
Melo-Ruíz Virginia*, Quirino-Barreda Tomás, García-Núñez Maritza, Díaz-García Rafael, Sánchez-Herrera \\ Karina and Schettino-Bermudez Beatriz \\ Departament of Biological Systems, Universidad Autonoma Metropolitana-Xochimilco, Mexico, D. F. 04960, Mexico
}

\begin{abstract}
Protein malnutrition is quite common worldwide; its deficiency has adverse effects in all organs. Edible insect's traditional cultural food, commonly consumed in rural communities, now intake is also being incorporated in some countries. Grasshoppers comprise proteins, the building blocks of AA (amino acids), that are one of the five classes of complex biomolecules found in cells and tissues that play an important role in human metabolism and nutrition. This research was conducted to determine proximal composition of Sphenarium purpurascens Ch, grasshoppers, focused on proteins and AA. Sampling was performed during autumn, 2013, in Oaxaca State. Dry raw adult insects were ground and proceeded to macro molecules proximal analysis, protein by Kjeldahl AOAC (Association of Official Analytical Chemists) method and essential AA in a Beckman 6300 equipment. Obtained data were: total proteins $71.56 \%$; lipids $8.14 \%$; minerals $3.52 \%$; fiber $7.48 \%$; soluble carbohydrates $9.30 \%$. Essential AA (mg/16 g.N): isoleucine 4.5; leucine 8.1; lysine 5.4; methionine + cysteine 5.1; phenylalanine + tyrosine 8.5; threonine 3.5; tryptophan 0.6; valine 5.5. Sphenarium purpurascens $\mathrm{Ch}$, Grasshoppers represent a good source of proteins and essential AA that can grow almost everywhere, available mostly all year round and affordable to all social groups, thus being a good option to improve human health.
\end{abstract}

Key words: Proteins, essential AA, nutrition, grasshoppers, Sphenarium purpurascen.

\section{Introduction}

Protein malnutrition is quite common worldwide; its deficiency has adverse effects in all organs, since they are the fundamental components of cellular functions. Edible insect's traditional cultural food, commonly consumed in rural communities, now intake is also being offered in gourmet restaurants in many countries. Grasshoppers, valued as a cheap source of fresh protein and essential AA (amino acids), have nowadays become part of the regular diet of several social groups. Proteins and essential AA found in cells and tissues, play an important role in human metabolism and nutrition. Sphenarium purpurascens $C h$ edible insects, commonly called grasshoppers, are classified in the Orthoptera order, Acridiidae family, and are reproduced almost everywhere in the wild, either in different cultivars or simple grass; they mate

\footnotetext{
*Corresponding author: Melo-Ruíz Virginia, Ph.D., research field: full experience in research of edible insects as food and nutrition.
}

at diversified agro climatic conditions once a year in the dry season, female digs into the soil an ooteca, mass with about 20 to 25 eggs, which hatch in the early spring and grow during summer and autumn reaching their adult stage. Grasshoppers are consumed either as nymphs or adults of their metamorphosis stage, raw or in different local preparations. The aim of this study was to assess the macronutrients in raw dry samples of Sphenarium purpurascens $C h$ according to AOAC (Association of Official Analytical Chemists) [1] techniques, focusing in proteins and essential AA, to inform of the benefits that grasshopper's consumption can provide to human health.

\section{Materials and Methods}

\subsection{Sample Collection and Preparation}

Convenience sampling of wild grasshoppers was performed in Oaxaca State, Mexico in an irregular area of about two kilometers, with slightly different agro climatic environments [2]. More than one specie 
was obtained in the studied area, but only one was kept for taxonomic determination [3] and proximal analysis by AOAC [1] methods. Collection was performed between 07:00 $\mathrm{h}$ and 09:00 h. Adults were manually and net captured in autumn 2013. Sphenarium purpurascenc $C h$ harvested at grassland area. The obtained insects were washed under running tap water and rinsed with distilled water and sun dried; they were transported in glass containers to the Metropolitan Autonomous University for further studies. Legs and wings were removed, individuals were homogenized by weight, each one to $0.7 \mathrm{~g}$.

\subsection{Determination of Moisture Content}

Sample moisture content was determined by using the direct drying method. Homogenized sample by weight of each organism, $(10 \mathrm{~g})$ was dried in an oven at $60{ }^{\circ} \mathrm{C}$ for $24 \mathrm{~h}$. Dry samples were powdered in a mortar, then passed through a 30 mesh size. The obtained fine powder was used for further analysis.

\subsection{Determination of Ash}

Ash was obtained by incinerating at $650{ }^{\circ} \mathrm{C}$ in a muffle furnace for $6 \mathrm{~h}$. to a constant weight, to eliminate the organic matter.

\subsection{Determination of Protein Content}

Sample protein content was determined according to the principle of the Kjeldahl method (AOAC method 945.01) [1]. Sample (1 g) was digested with $15 \mathrm{~mL}$ concentrated sulfuric acid, using an electrically heated aluminum block digester. The resulting digest was diluted and then made alkaline with $50 \mathrm{~mL}, 40 \%$ sodium hydroxide. This was followed by rapid steam distillation of ammonia from the diluted digest into 25 $\mathrm{mL} 4 \%$ boric acid for manual titration with $0.2 \mathrm{~N}$ hydrochloric acid. A convention factor of 6.25 was used to convert the measured nitrogen content to protein content. All samples were analyzed in triplicate and the results were expressed as $\mathrm{g} / 100 \mathrm{~g}$ dry basis of sample $[4,5]$.

\subsection{Determination of Lipid Content}

Lipid content determination was performed by the semi continuous solvent extraction method (AOAC method 934.01) [1] as follows: sample (10 g) was extracted with $180 \mathrm{~mL}$ petroleum ether on a Soxhlet apparatus for $10 \mathrm{~h}$. Petroleum ether was removed by evaporation and the lipid residue was weighed. All samples were analyzed by triplicate and the results are expressed as $\mathrm{g} / 100 \mathrm{~g}$ dry basis of sample.

\subsection{Determination of Fiber}

Sample raw fiber $(10 \mathrm{~g})$ was performed by acid hydrolysis with $\mathrm{H}_{2} \mathrm{SO}_{4} 0.255 \mathrm{~N}$ followed by alkaline hydrolysis with $\mathrm{NaOH} 0.313$ N. Sample was analyzed by triplicate and results expressed as $\mathrm{g} / 100 \mathrm{~g}$ dry basis.

\subsection{Determination of Soluble Carbohydrates}

Carbohydrate content on dry weight basis was calculated by difference $[100-$ (protein + lipids + ash + raw fiber)].

\subsection{Determination of $A A$}

Grasshoppers sampled for amino acid analysis were hydrolyzed in constant with $6 \mathrm{~N} \mathrm{HCl}$ for $24 \mathrm{~h}$. at $110{ }^{\circ} \mathrm{C}[6]$ and evaporated under vacuum steam; the sample was then resuspended in the NA-S buffer and injected to the system. For the analysis of methionine and cysteine, samples were oxidized with performic acid before hydrolysis. AA were determined by the HPLC (high performance liquid chromatography) technique, using an automatic autoanalyzer Beckman System Gold model 6300 that includes a solvent module 120 AA, post column reactor 232, detector 166, autosampler 507, a column of cation exchange resin $(3 \times 250 \mathrm{~mm}$ spherogel AA sodium column sulfonated polystyrene-divinylbenzene copolymers), diluted with a gradient of buffers with a concentration of $0.2 \mathrm{M}$ to $2 \mathrm{M}$ of citrate and $\mathrm{pH} 3.1$ to 5.6 and a computer work station [7]. Tryptophan was measured 
according to the colorimetric method after enzymatic hydrolysis [8]. Triplicate analyses were performed for each sample.

\section{Results}

Insect availability per month is shown in Table 1.
Moisture and macronutrients composition.

Almost one third of the insect is water, as shown in Table 3 .

\section{Discussions}

Grasshoppers, Sphenarium purpurascens Ch,

Table 1 Year availability of Grasshoppers Sphenarium purpurascens Ch in Oaxaca State, 2013.

\begin{tabular}{llllllllllllll}
\hline Species/month & J & F & M & A & M & J & J & A & S & O & N & D \\
\hline Sphenarium purpurascens $C h$ & & & & X & X & x & X & X & X & X & X & X \\
\hline
\end{tabular}

$\mathrm{X}=$ Abundant; $\mathrm{x}=$ low; seasonal availability depends on the biotic and abiotic conditions.

Table 2 Taxonomy determination and name.

\begin{tabular}{ll}
\hline Clase & Insecta \\
\hline Order & Orthoptera \\
Family & Acrididae \\
Genus & Sphenarium \\
Specie & purpurascens Ch \\
Common name: & Grasshopper \\
\hline
\end{tabular}

Table 3 Water content in Grasshopper Sphenarium purpurascens Ch (\%).

\begin{tabular}{ll}
\hline Species & Sphenarium purpurascens $C h$ \\
\hline Moisture & $39.18 \%$ \\
Dry sample & $60.82 \%$ \\
\hline
\end{tabular}

Moisture in grasshoppers was $39.18 \%$ and $60.82 \%$ in dry samples. Results can change according to biotic and abiotic conditions in the environment.

Table 4 Proximal composition of Grasshoppers Sphenarium purpurascens Ch (g/100g dry basis).

\begin{tabular}{ll}
\hline & Sphenarium purpurascens Ch \\
\hline Proteins & $75.56 \pm 0.8$ \\
Lipids & $8.14 \pm 0.2$ \\
Minerals & $3.52 \pm 0.7$ \\
Crude fiber & $7.48 \pm 0.6$ \\
Soluble carbohydrates & 9.30 \\
Energetic value (Kcal/100g) & 412.7 \\
\hline All & \\
\hline
\end{tabular}

All values are mean \pm standard deviation of samples analyzed in triplicate.

Protein $=$ Kjeldahl $\mathrm{N} \times 6.25$

Energetic value was calculated multiplying soluble carbohydrates and proteins by 4 and lipids by 9 , to obtain the Kcal amount.

Table 5 Essential AA in adult Sphenarium purpurascens $C h(\mathbf{m g} / 16 \mathrm{~g} \cdot \mathbf{N})$.

\begin{tabular}{lll}
\hline Essential AA & Sphenarium purpurascens $C h$ & FAO pattern 2007 \\
\hline Isoleucine & 4.5 & 4.0 \\
Leucine & 8.1 & 7.0 \\
Lysine & 5.4 & 5.5 \\
Methionine + Cysteine & 5.1 & 3.5 \\
Phenylalanine + Tyrosine & 8.5 & 6.0 \\
Threonine & 3.5 & 4.0 \\
Tryptophan & 0.6 & 1.0 \\
Valine & 5.5 & 5.1 \\
\hline
\end{tabular}

FAO (Food Agriculture Organization) pattern for Methionine 3.5 and Phenylalanine 6.0. Report Sulphur amino acid. Methionine + Cysteine 5.1 and Aromatic amino acid. Phenylalanine + Tyrosine 8.5. 
Table 6 Non essential AA in adult Sphenarium purpurascens $C h(\mathrm{mg} / 16 \mathrm{~g} \cdot \mathrm{N})$.

\begin{tabular}{ll}
\hline AA & Sphenarium purpurascens Ch \\
\hline Histidine & 2.5 \\
Aspartic acid & 9.5 \\
Glutamine acid & 9.8 \\
Serine & 4.7 \\
Proline & 6.3 \\
Glysine & 5.5 \\
Alanine & 6.9 \\
Arginine & 6.7 \\
\hline
\end{tabular}

Histidine and arginine are essential for infants. Asparagine and Glutamine can be synthesized from aspartic acid and glutamic acid.

proximal composition (Table 4) can vary according to the abiotic agro climatic conditions of the environment and plant chemical composition, since they feed on them to acquire the nutrients necessary for reproduction, growth, and general maintenance. Grasshoppers have the ability to biosynthesize some nutrients, although most of the nutrients they need are provided by their plant-host.

Climatic conditions also affect the host-vegetation and play an important role in the insect reproduction and growth. Data obtained in the present study slightly range in values already published [9]; however, those differences might be due to the in which the sample was harvested or the size of the insects. The moisture and macromolecules of Sphenarium purpurascens $C h$ are presented in Tables 3 and 4, proteins are considerably high, minerals were not quantified individually and fatty acids were in a balanced amount, soluble carbohydrates source of energy were low; however, insect can convert AA to carbohydrates via gluconeogenesis, regarding AA (Tables 5 and 6) insects have all essential AA in similar proportions to requirements.

Insects use AA to build proteins for structural purposes; as enzymes, for transport and storage, or as a receptor molecule. Individual AA also are involved in important physiological functions in human health such as Leucine, translation and transcriptional regulator; Arginine and Phenylalanine, regulators of enzyme activities; Tryptophan, neurotransmitter; Alanine, Glutamine and Leucine, transporter of nitrogen in the brain. AA can regulate protein synthesis at the transcriptional level.

\section{Conclusions}

Protein is the fundamental component for cellular and organs functions. Daily diet must contain not only enough protein and AA, but also sufficient non-protein energy to permit optimal utilization of dietary protein. Protein energy malnutrition is quite common in the world. Protein deficiency has adverse effects on all organs, it reduces immune functions; therefore, humans become more susceptible to infections. Grasshoppers are a source of cheap protein. They can reproduce wherever any vegetation grows, and they are available mostly all year round. They have a good nutritional value and they have been consumed since ancient times by different social groups, maybe not in a regular basis but every once in a while as snacks; nevertheless, their regular intake in the diet, could represent a good option to improve human health.

\section{References}

[1] AOAC. 1995. Official Methods of Analysis, Association of Official Analytical Chemists. 15th ed., Washington, DC.

[2] Greenfield, H., and Southgate, D. A. T. 2003. Food Composition Data: Production Management and Use. 2nd ed., Rome: Publisher FAO, 63-82.

[3] Osborne, D. R. 1985. Nutrient Analysis of Foods. Zaragoza: Acribia.

[4] Pearson, D. 1989. Laboratory Technics for the Food Analysis. Zaragoza: Acribia. 
[5] Gehrke, C. W., Rexroad, P. R., Schisla, R. M., Absheer, J. S., and Zumwalt, R. W. 1987. "Quantitative Analysis of Cysteine, Methionine, Lysine and Nine Other Amino Acids by a Single Oxidation-4h Hydrolysis Method." Journal of the Association of Official Analytical Chemists 70 (1): 171-4.

[6] Beckman. 1985. The System 6300 Series High Performance Amino Acids Analyzer. Instruction Manual. Spinco Division of Beckman, Division Instruments. Palo Alto, California, 218.

[7] Holz, F. 1972. "Automatic Determination of Tryptophan in Proteins and Protein-containing Plant Products with Dimethylaminocinnamaldehyde." Landwirsh Forsh
Sonderh 27: 96-109.

[8] FAO/WHO/UNU. 2007. "Protein and Amino Acids Requirements in Human Nutrition: Report of a Joint FAO/WHO/UNU Expert Consultation. WHO Technical Series, 935." Accessed August 17, 2009. http:// www.whqlib-doc.who.int/trs/WHO_TRS_935_eng. pdf.

[9] Melo-Ruíz, V., Sandoval-Trujillo, H., Quirino-Barreda, T., Sánchez-Herrera, K., Díaz-García, R., and Calvo-Carrillo, C. 2015. "Chemical Composition and Amino Acids Content of Five Species of Edible Grasshoppers from Mexico." Emirates Journal of Food and Agriculture 27 (8): 654-8. 